\title{
Particle flux in an Antarctic shallow coastal environment: a sediment trap study*
}

\author{
IRENE R. SCHLOSS ${ }^{1}$, GUSTAVO A. FERREYRA ${ }^{1}$, GUILLERMO MERCURI ${ }^{1}$ \\ and JENS KOWALKE ${ }^{2}$ \\ ${ }^{1}$ Instituto Antártico Argentino, Cerrito 1248, (1010) Buenos Aires, Argentina. \\ ${ }^{2}$ Alfred-Wegener-Institut für Polar- und Meeresforschung, PO Box 120161, D-27515, Bremerhaven, Germany.
}

\begin{abstract}
SUMMARY: Sediment trap arrays were deployed at Potter Cove, King George Island, Antarctica, between December 1991 and August 1992 and in the summer seasons of 1993-1994, and 1995. The sampling sites reached $30 \mathrm{~m}$ depth, and traps were placed during the different seasons at various distances from the sea bottom $(0.1$ to $25 \mathrm{~m})$, some being buried in the sediments. Daily sedimentation rates of total particulate matter (TPM) and chlorophyll-a were estimated. Water column temperature and salinity as well as pigment and TPM concentration were also measured and related to traps' results. Water column data evidenced processes in relation with phytoplankton dynamics, stormy events and particles containing fresh water runoff. Similar trends were observed in the traps located at $25 \mathrm{~m}, 1 \mathrm{~m}$ and sometimes even in those located to around $0.1 \mathrm{~m}$ from sea bottom, although traps buried in the sediments mainly reflected resuspension events. Chlorophyll $a$ fluxes were higher in the bottom traps, but the sedimented organic fraction of the TPM (particulate organic matter, POM) was higher in the traps located remotely from the bottom, being significantly lower in the buried traps (i.e. POM represented 50\% of TPM at $1 \mathrm{~m}$ and 9\% POM in the buried trap on November 23 in 1993, although a great variability among sampling dates was also observed). The significance of these dynamics for the food availability for the macrozoobenthic organisms present in the area is discussed.
\end{abstract}

Key words: Antarctica, organic and inorganic particles, shallow coastal environments, sediment traps, benthic communities.

RESUMEN: FLUJO DE PARTí́CULAS EN UN AMBIENTE COSTERO ANTÁRTICO DE AGUAS SOMERAS: UN ESTUDIO CON TRAMPAS DE SEDIMENTO. - Entre diciembre de 1991 y agosto de 1992 y durante las campañas de verano de 1993-1994 y 1995 se estudió la tasa de sedimentación de partículas en Caleta Potter, Isla King George - 25 de Mayo, Antártida, mediante el empleo de trampas de sedimento. La profundidad en los sitios de muestreo fue de $30 \mathrm{~m}$. Las trampas fueron colocadas a distintas distancias del fondo $(0,1 \mathrm{a} 25 \mathrm{~m})$, habiéndose enterrado algunas en los sedimentos. Se estimaron las tasas diarias de sedimentación para el total de material particulado y los pigmentos. Se midieron además la temperatura y la salinidad, así como la concentración de material particulado total y pigmentos en la columna de agua. Estos parámetros fueron relacionados con aquellos de las trampas de sedimento. Los resultados de la columna de agua reflejaron procesos relacionados con la dinámica del fitoplancton, eventos de tormentas y aportes terrígenos de agua dulce. Esto fue válido para las trampas colocadas a $25 \mathrm{~m}, 1 \mathrm{~m}$ y en ocasiones aún para aquellas colocadas a $0,1 \mathrm{~m}$, si bien los datos obtenidos de las trampas enterradas en el sedimento se relacionan con episodios de resuspensión. Los flujos de clorofila $a$ fueron mayores en las trampas más cercanas al fondo, pero la fracción orgánica del material particulado sedimentada fue significativamente menor en las trampas enterradas. Por ejemplo, el porcentaje de materia orgánica en las trampas del 23 de noviembre de 1993 fue de $50 \%$ a 1 m y del $9 \%$ en la trampa enterrada en los sedimentos, si bien pudo observarse una gran variabilidad entre fechas de muestreo. Se discute la importancia de esta dinámica para la nutrición de los organismos del macrozoobentos presentes en el área.

Palabras clave: Antártida, partículas orgánicas e inorgánicas, ambientes costeros de aguas someras, trampas de sedimento, comunidades bentónicas.

This is AWI contr. no. 1753

*Accepted November 4, 1998. 


\section{INTRODUCTION}

Particulate organic matter (POM) in the water column in Antarctic shallow coastal environments can have different origins. The amount and quality of POM is of great importance for benthic filter feeders, which can sometimes reach very high densities in these environments (Cattaneo-Vietti et al., 1997). This is also valid for Potter Cove (South Shetland Islands, Antarctica), as described by Sahade et al. (1998) and Mercuri et al. (1998), where the studies here presented were done. Phytoplankton and water column primary production pulses have been long considered to be one of the main sources of POM for zoobenthos nourishment (Barnes and Clarke, 1995; Albertelli et al., 1996). However, in the vicinities of the studied area several authors showed that total phytoplankton biomass was very low (Hapter et al., 1983, Brandini and Rebello, 1994), and this has also been observed in Potter Cove (Schloss, 1997; Schloss et al., 1997). Several studies suggested that benthic resources (microphytobenthos, detritic material, bacteria, macroalgae debris, etc.) would play a significant role in supporting the high stocks of macrozoobenthic organisms observed in the area (Reichardt and Dieckmann, 1985; Ahn, 1993, 1997; Schloss, 1997). An additional source of POM available for benthic filter feeders could come from land-derived inputs, which at times become quantitatively important (Schloss et al., 1997), or from sediment resuspension (Berkman et al., 1986). These materials could settle and reach the bottom organisms. The different sources of POM mentioned and their availability for benthic animals varies seasonally, especially in highly cyclic environments like Antarctica (Clarke and Leakey, 1996). POM availability for the different benthic animals may also be different according to their habitats (i.e. whether they live buried or above the sea bottom's surface), and to the size (height) they can achieve.

Sediment traps are good tools for the estimation of the vertical rate of displacement of particles travelling towards the bottom of the sea (Bodungen et al., 1986; Wassman, 1991). Here we report the results of a series of sediment trap studies, which were performed at different depths during contrasting seasons. The aim of this investigation was to understand the dynamics of particles in a shallow coastal environment of Antarctica with low pelagic primary productivity. We present three data sets, one based on a monthly sampling during half a year, from late spring to winter; a second one at several depths during spring and summer, and a third one from springtime, to test also the effect of the different exposure intervals on the trap content.

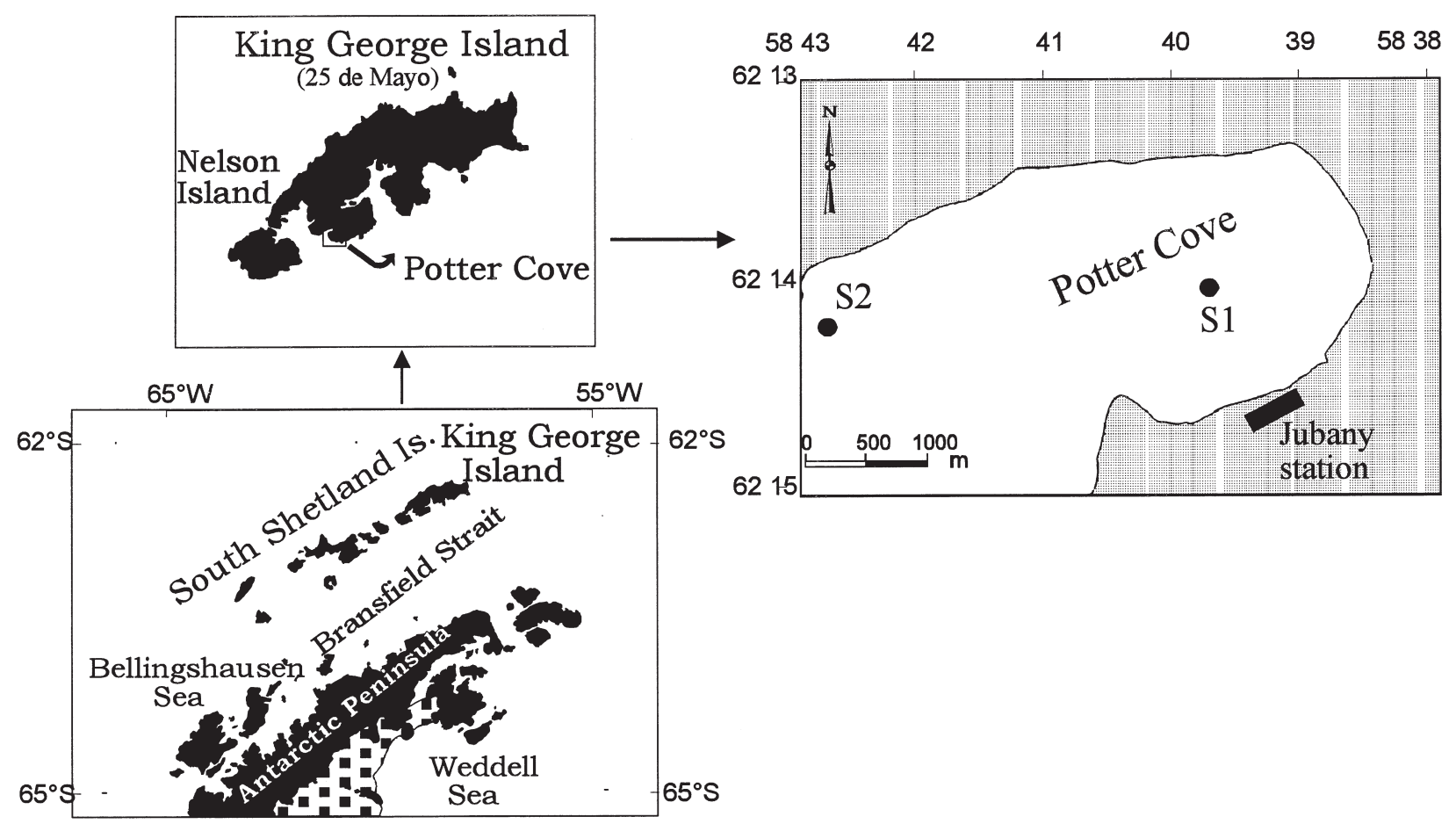

FIG. 1. - Map showing the location of King George Island and Potter Cove. Sampling sites S1 and S2 are indicated. 


\section{MATERIAL AND METHODS}

\section{Study site}

This study was carried out in the vicinity of Jubany Station, at Potter Cove (King George-25 de Mayo Island, South Shetland Islands, 62 ${ }^{\circ} 14^{\prime}$ S, $58^{\circ} 38^{\prime}$ W, Fig. 1), a small tributary embayment inside Maxwell Bay. There, two zones can be distinguished: an inner cove, where maximal depths can reach $50 \mathrm{~m}$ (average $=30 \mathrm{~m})$, and an outer deeper cove $(>100$ $\mathrm{m})$. Muddy soft bottoms are characteristic of the inner cove, whereas the outer cove is bordered by hard substrate shores down to $30 \mathrm{~m}$ (Klöser et al., 1994a). Each area also presents different community characteristics. Filter feeders (Sahade et al., 1998, Urban and Mercuri, 1998) and microphytobenthic algae (Mercuri et al., 1998) dominate the inner cove while the outer cove presents high densities of macroalgae (Klöser et al., 1994b). During the 1991-1992 campaign both places were studied; the sampling sites were named S1 and S2 for the inner and the outer cove, respectively (Fig. 1), and the depth in both of them reached around $30 \mathrm{~m}$. Data from 1993-94 and 1995 correspond only to the inner cove (S1).

\section{Sediment traps}

Cylindrical PVC traps $(21.6 \mathrm{~cm}$ in length and $3.7 \mathrm{~cm}$ in diameter, $\mathrm{h} / \mathrm{d}=5.8$, Lange and Boltovskoy, 1995) were used. This size is adequate for an environment such as Potter Cove, where current speed at the traps' deployment depths is very low (Roese, 1998). Traps were placed in the water without fixative, as in Fabiano et al. (1997), and handled manually by SCUBA divers, in accordance with the recommendations given for the EASIZ Programme (SCAR, 1994). Although a short deployment period is ideal to reduce contamination by zooplankton and carbon losses produced by respiration processes (Bloesch and Burns, 1980), sometimes traps were left during long periods due to persistent bad weather conditions. An estimation of the effect of a longer permanence on the content of the traps is presented here.

TABLE 1. - Some methodological information about the different sediment trap studies performed. B: traps located with their openings some $5 \mathrm{~mm}$ above the sea bottom. Dashed lines separate different campaigns.

\begin{tabular}{|c|c|c|c|c|c|}
\hline $\begin{array}{l}\text { Starting date } \\
\text { Year }\end{array}$ & Month, day & Sampling site & $\begin{array}{l}\text { Number of } \\
\text { replicates }\end{array}$ & Days of exposure & $\begin{array}{l}\text { Distance from } \\
\text { bottom }(\mathrm{m})\end{array}$ \\
\hline \multirow[t]{4}{*}{1991} & December 3 & $\mathrm{~S} 1$ & 2 & 5 & 2 \\
\hline & December 9 & S1 & 2 & 6 & 2 \\
\hline & December 14 & $\mathrm{~S} 1, \mathrm{~S} 2$ & 2 & 5 & 2 \\
\hline & December 20 & $\mathrm{~S} 1, \mathrm{~S} 2$ & 2 & 5 & 2 \\
\hline \multirow[t]{9}{*}{1992} & January 27 & $\mathrm{~S} 1, \mathrm{~S} 2$ & 2 & 7 & 2 \\
\hline & February 2 & $\mathrm{~S} 2$ & 1 & 7 & 2 \\
\hline & February 21 & $\mathrm{~S} 1$ & 2 & 14 & 2 \\
\hline & March 30 & S1 & 2 & 7 & 2 \\
\hline & April 3 & $\mathrm{~S} 2$ & 2 & 10 & 2 \\
\hline & May 5 & $\mathrm{~S} 1, \mathrm{~S} 2$ & 2 & 16 & 2 \\
\hline & June 5 & S1 & 2 & 31 & 2 \\
\hline & July 15 & $\mathrm{~S} 1$ & 2 & 25 & 2 \\
\hline & August 15 & S1 & 2 & 31 & $\frac{2}{2}$ \\
\hline \multirow[t]{7}{*}{1993} & November 1 & $\mathrm{~S} 1$ & $2-3$ & 5 & $1,0.5,0.25,0.1, \mathrm{~B}$ \\
\hline & November 15 & $\mathrm{~S} 1$ & 3 & 3 & $1,0.5,0.25,0.1, \mathrm{~B}$ \\
\hline & November 19 & $\mathrm{~S} 1$ & 3 & 4 & $1,0.5,0.25,0.1, \mathrm{~B}$ \\
\hline & December 18 & S1 & 3 & 3 & $1,0.5,0.25,0.1, \mathrm{~B}$ \\
\hline & December 21 & $\mathrm{~S} 1$ & 3 & 4 & $1,0.5,0.25,0.1, \mathrm{~B}$ \\
\hline & December 25 & $\mathrm{~S} 1$ & 3 & 6 & $1,0.5,0.25,0.1, \mathrm{~B}$ \\
\hline & December 31 & S1 & $2-3$ & 7 & $1,0.5,0.25, \mathrm{~B}$ \\
\hline \multirow[t]{4}{*}{1994} & January 7 & $\mathrm{~S} 1$ & 3 & 4 & $1,0.5,0.25,0.1, \mathrm{~B}$ \\
\hline & January 11 & $\mathrm{~S} 1$ & 3 & 3 & $1,0.5,0.25,0.1, \mathrm{~B}$ \\
\hline & January 14 & $\mathrm{~S} 1$ & $1-3$ & 5 & $1,0.5,0.25,0.1, \mathrm{~B}$ \\
\hline & January 25 & $\mathrm{~S} 1$ & 3 & 2 & $1,0.5,0.25,0.1, \mathrm{~B}$ \\
\hline & November 6 & $\mathrm{~S} 1$ & 3 & 1.5 & 25 \\
\hline & November 7 & $\mathrm{~S} 1$ & 3 & 1 & 25 \\
\hline & November 24 & $\mathrm{~S} 1$ & 3 & 1.5 & 25 \\
\hline & November 27 & $\mathrm{~S} 1$ & 3 & 1 & 25 \\
\hline & November 29 & $\mathrm{~S} 1$ & 3 & 1 & 25 \\
\hline & November 30 & S1 & 3 & 1 & 25 \\
\hline & December 1 & S1 & 2 & 1 & 25 \\
\hline & December 1 & S1 & 2 & 2 & 25 \\
\hline & December 1 & S1 & 2 & 4 & 25 \\
\hline & December 2 & $\mathrm{~S} 1$ & 2 & 1 & 25 \\
\hline & December 3 & $\mathrm{~S} 1$ & 2 & 2 & 25 \\
\hline
\end{tabular}




\section{1 - 1992 season}

From December 1991 to August 1992 the trap arrays were placed in $\mathrm{S} 1$ and on six occasions in $\mathrm{S} 2$, at $2 \mathrm{~m}$ from the bottom (Table 1). Traps were left in the water for periods between 7 and 14 days, except during the winter, when on occasions they could only be recovered after a month. Although for Antarctic coastal shallow environments monthly clearing of the traps is recommended during winter (SCAR, 1994), in these cases only total particulate matter data were considered in the analyses.

\section{3 - 1994 season}

During the summer season 1993/94 sediment traps were deployed in the central inner cove (S1). Traps were attached to steel stickes and fixed to the bottom. 15 traps were spread in an area of $10 \mathrm{~m}^{2}$, with their mouth exposed at 5 depths (Table 1): 1, 0.5, 0.25, $0.1 \mathrm{~m}$ from sea bottom, and at the water-sediment interface, traps buried in the sediments, some $5 \mathrm{~mm}$ from the sea bottom. For each depth, three traps (replicates) were deployed. This design was repeated in 10 opportunities. Each array remained in the water between 2 and 5 days, except on one occasion, when due to adverse meteorological conditions the array was left for 7 days.

\section{5 season}

In November-December 1995 three traps (replicates) were located at $5 \mathrm{~m}$ from the water surface (around $25 \mathrm{~m}$ from the bottom), coinciding approximately with the depth of the pycnocline, on 10 occasions. Between December 1 and 5, traps were placed and removed in such a way as to allow a comparison of the results of the traps' catch after 1, 2 or 4 days in the field (Table 1). Therefore, on December 1, 6 traps were placed on a star-like frame, and on December 2, 3 of them were extracted and replaced by another 3 . On December 3, all 6 traps were removed, thus comparing the content of traps staying 1 and 2 days in the water. The same sampling design was followed between December 3 and 5, letting the three traps stay for 2 and 4 days. The percentile loss of materials from the traps was estimated by the difference between the sum of the consecutive samples and the ones that stayed for the whole period.

\section{Analyses}

Immediately after removal, trap content was gently mixed. Traps where zooplankton was found inside were not analysed. Chlorophyll-a was measured on 90\% acetone extracts after filtration through Millipore filters (during spring 1991 and 1993-94 seasons) or through Whatman GF/F filters (during the 1995 season, when phaeopigments were also estimated), and read in a Hitachi Perkin Elmer or a Shimadzu spectrophotometer in each case, following Strickland and Parsons (1972). The organic and inorganic fractions of total particulate matter (TPM) were measured gravimetrically after filtering the samples through combusted preweighed Whatman GF/F filters. After filtration filters were rinsed twice with distilled water in order to remove salts, then dried $24 \mathrm{~h}$ at $60^{\circ} \mathrm{C}$, and weighed. The organic fraction was estimated as the difference between TPM and the remains after 5-h combustion at $500^{\circ} \mathrm{C}$. For the 1992 winter traps only TPM was considered, due to the long exposure of the traps. In the 1995 campaign particle concentration and size distribution were measured on $30 \mathrm{ml}$ subsamples taken immediately after recovery of the traps. An Elzone 280 Particle Counter equipped with an orifice-tube of $60 \mathrm{~mm}$ was used for this purpose. The particles were measured over a range from 0 to $30 \mathrm{~mm}$. Daily sedimentation rates were calculated after Baines and Pace (1994).

Parallel measurements of chlorophyll-a and TPM were done on water column samples collected with a 51 Niskin bottle at $0,5,10,20$ and $30 \mathrm{~m}$ depth, following the same methods described for the trap samples. Water column temperature and salinity were measured using a WTW-LF191 thermoconductimeter, and the anomaly of density $\left(\sigma_{t}\right)$ was calculated after Fofonoff and Millard (1983). During the 1995 season particle analysis was also done on water column samples; only those corresponding to 0 and $5 \mathrm{~m}$ were considered in the comparison with particles from the traps. The procedure for this analysis was the same as that described above for the traps.

\section{RESULTS}

\section{1 - 1992 season}

(traps located at $2 \mathrm{~m}$ from the sea bottom)

During summer TPM flux into the traps was around $10 \mathrm{~g} \mathrm{~m}^{-2} \mathrm{~d}^{-1}$, but sedimentation rates as high as $130 \mathrm{~g} \mathrm{~m}^{-2} \mathrm{~d}^{-1}$ were measured in S1 and S2 (Fig. 2- 
a)

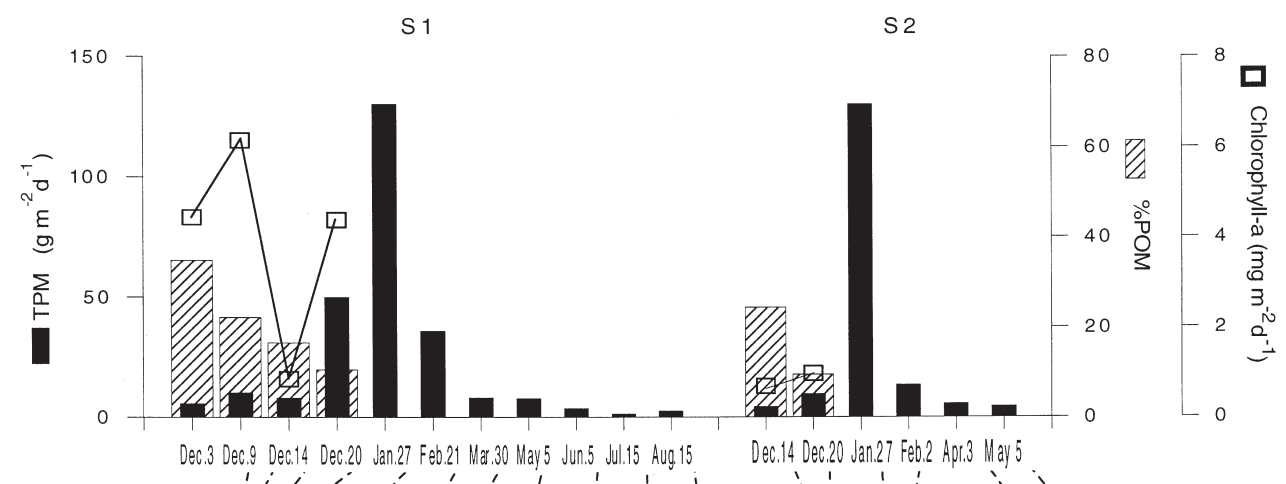

b) $\quad \sigma_{t}$
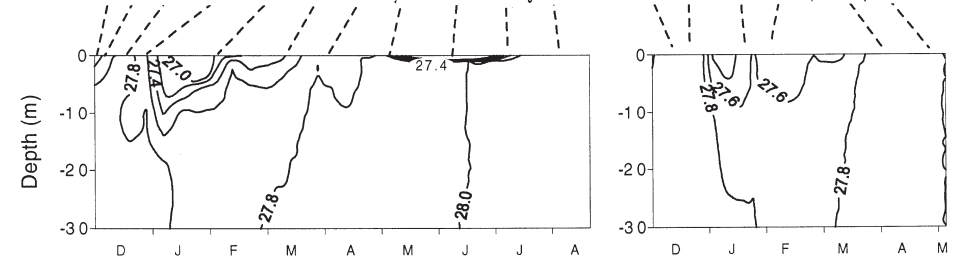

Chlorophyll-a $\left(\mu \mathrm{g} \mathrm{I}^{-1}\right)$
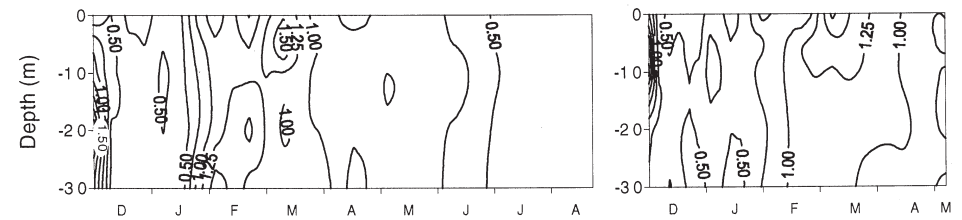

$\operatorname{TPM}\left(\mathrm{mg} \mathrm{I}^{-1}\right)$
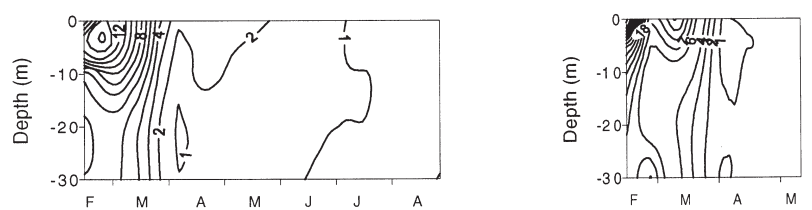

$\%$ POM
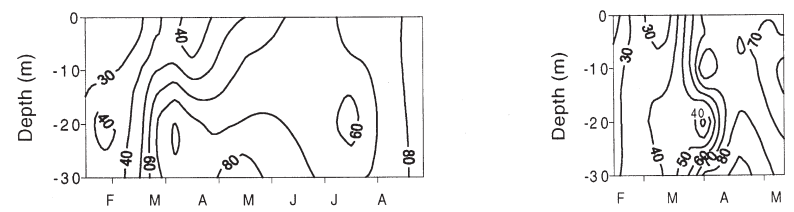

FIG. 2. - a) TPM (filled bars), \%POM (striped bars) and chlorophyll-a fluxes (empty squares) measured from the trap contents during the 1991-1992 study. Dates on the x-axis correspond to the deployment of the traps. b) Density anomalies, TPM, \%POM and chlorophyll-a concentrations in the water column during the same period. Note that TPM sampling only started in February 1992.

a), in coincidence with an increase in freshwater input from the land. This was evidenced by the surface $\sigma_{t}$ values at that time (Fig. 2-b). There are no TPM (or POM) data from the water column available for the early sampling days during this period. The average organic fraction (\%POM) in the traps was $12.56 \%$, with maxima on December 3 and 9 in S1 (35 and 22\% respectively). They were associated with high chlorophyll-a sedimentation rates (around $4.5 \mathrm{mg} \mathrm{m}^{-2} \mathrm{~d}^{-1}$ ), as well as high pigment concentration in the water column. There, chlorophyll-a maxima were around $1.5 \mu \mathrm{g} \mathrm{l}^{-1}$ (Fig. 2-b) in early December. There was no difference between both stations in pigment concentrations in the water col- umn. On December 14, when both S1 and S2 were studied, the relatively high \%POM $(24 \%)$ was not associated with the chlorophyll-a sedimentation rate (i.e. $0.86 \mathrm{mg} \mathrm{m}^{-2} \mathrm{~d}^{-1}$ in S2, Fig. 2-a). Unfortunately, for this date we do not have information on water column POM with which to relate this result. In general, chlorophyll-a fluxes in the traps were always higher in $\mathrm{S} 1$ than in $\mathrm{S} 2$.

Only a few water samples were collected in S2 during winter, but although absolute amounts of TPM and POM were lower than in S1 (Fig. 2-b), the $\%$ POM was similar in both places (Fig. 2-a). It could also be noted that the \%POM was relatively more important during the winter than in summer. 
a)

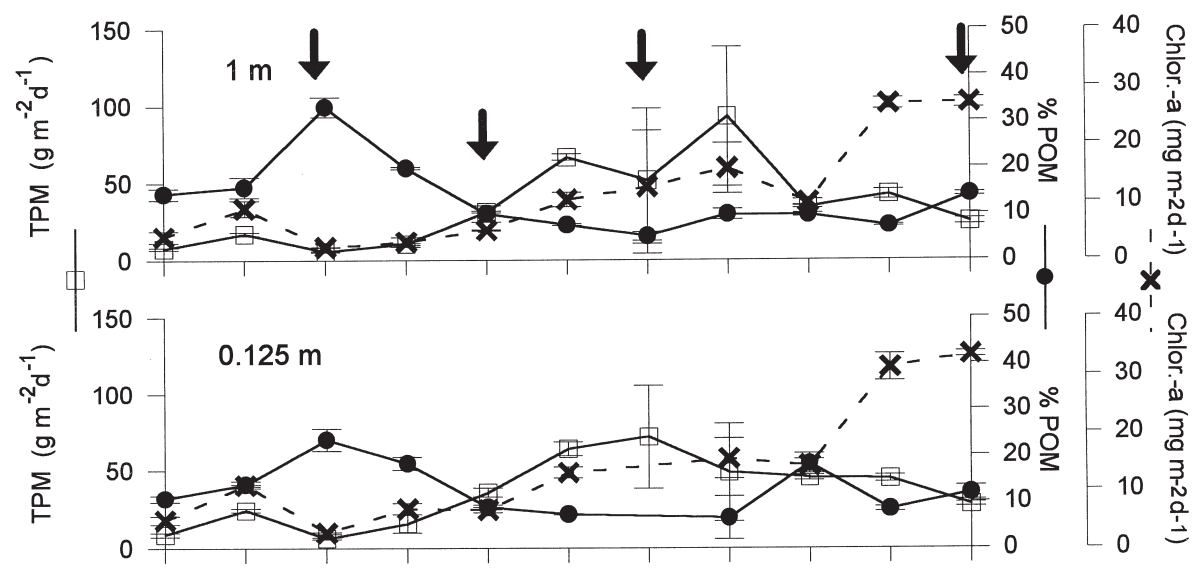

Nov.1 Nov.15 Nov.19 Dec.18 Dec.21 Dec.25 Dec.31 Jan.7 Jan.11 Jan.14 Jan.22

b)
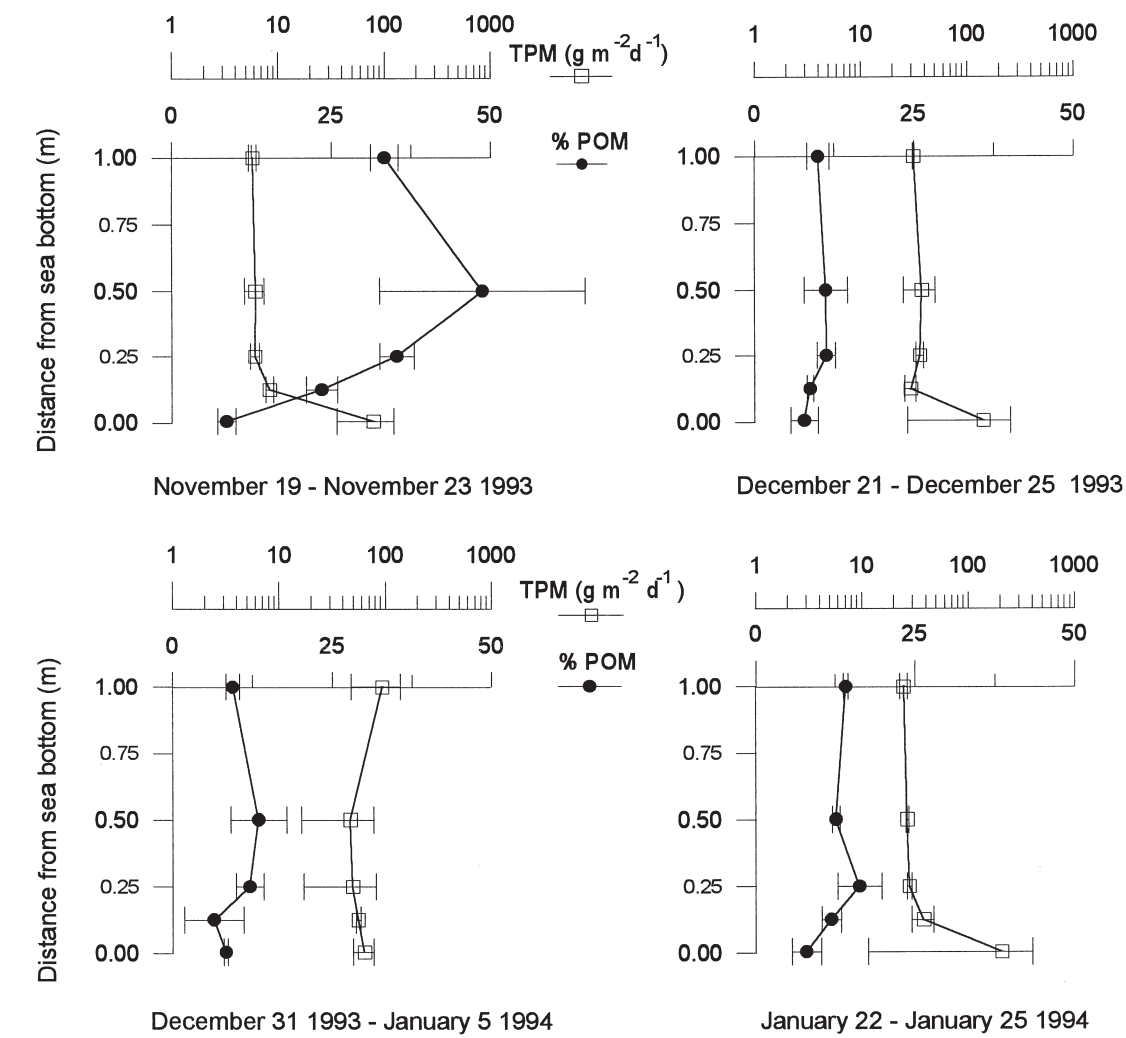

FIG. 3. - a) Temporal variation in TPM (empty square), POM (-.-) and chlorophyll-a (-x-) fluxes measured in the traps located $1 \mathrm{~m}$ and 0.1 $\mathrm{m}$ from sea bottom during the 1993-1994 season. Dates on the $\mathrm{x}$-axis correspond to the deployment of the traps. Arrows indicate selected dates for which the whole vertical TPM and \%POM profiles are shown in the graphs in b). Vertical and horizontal bars represent standard errors.

\section{3 - 1994 season}

(traps located between 0-1 $\mathrm{m}$ from the sea bottom)

The temporal pattern observed for TPM, POM and chlorophyll-a in the $1 \mathrm{~m}$ and $0.1 \mathrm{~m}$ traps during the 1993-1994 summer season (Fig. 3-a) showed an increase in particle sedimentation rate between December 25, 1993 and January 7, 1994, in coinci- dence with an increase of TPM in the water column (Fig. 4-b). This can be related to a marked landderived fresh water input, evidenced in the low surface $\sigma_{t}$ values measured during that period in the water column (Fig. 4-a). The increase in the chlorophyll-a flux observed during the last two sampling dates (up to $35 \mathrm{mg} \mathrm{m}^{-2} \mathrm{~d}^{-1}$ ) could also be correlated with an increase in the concentration of this pigment 


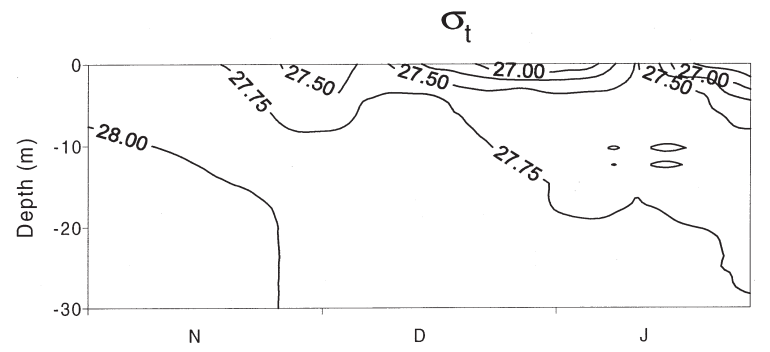

Chlorophyll-a $\left(\mu \mathrm{g} \mathrm{I}^{-1}\right)$

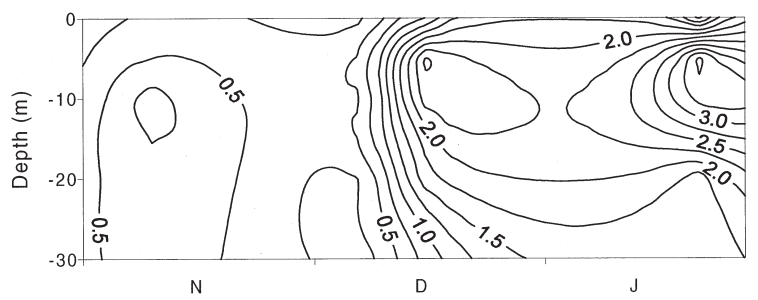

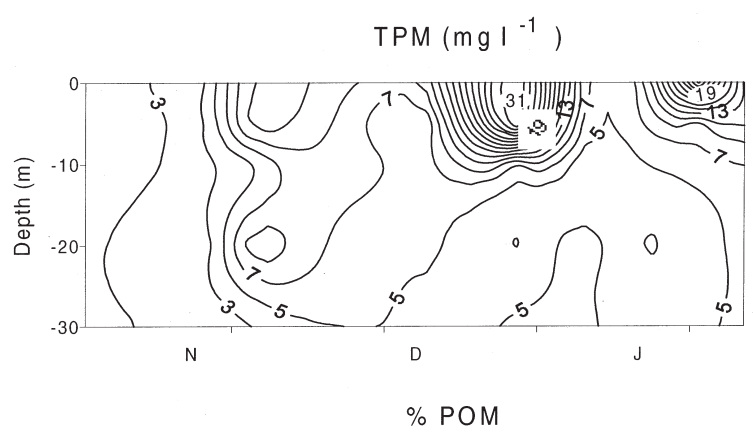

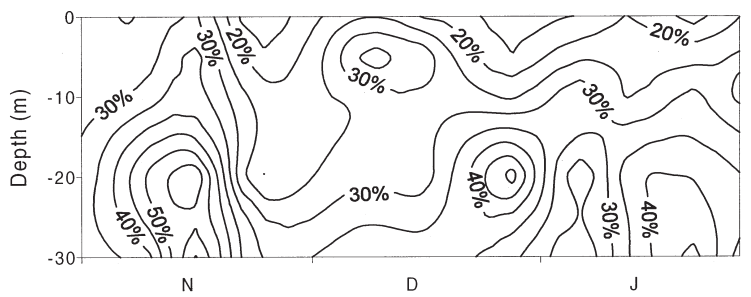

FIG. 4. - Temporal distribution of some water column parameters during the summer season 1993-1994, when sediment trap studies were performed. a) $\sigma_{\mathrm{t}}$; b) TPM $\left(\mathrm{mg} \mathrm{l}^{-1}\right)$, c) Chlorophyll-a $\left(\mathrm{mg} \mathrm{l}^{-1}\right)$; d) \%POM.
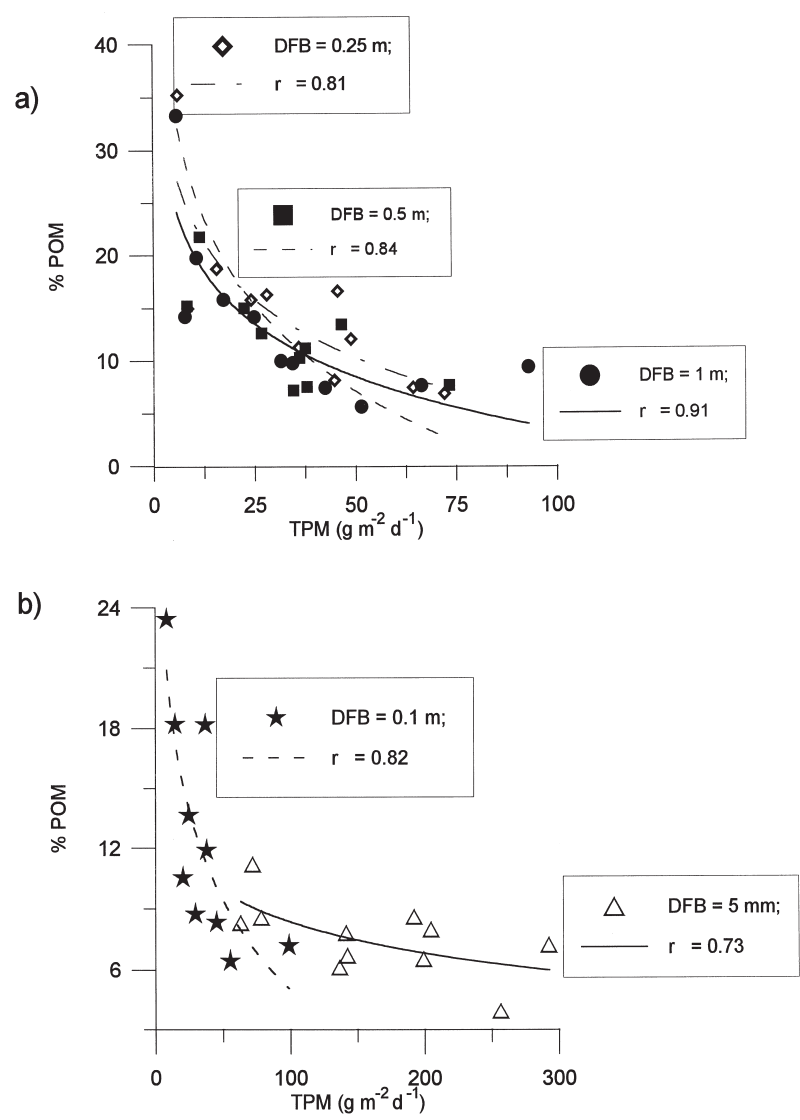

FIG. 5. - Regression between the TPM and \%POM fluxes in the traps deployed at 5 distances (from sea bottom, $5 \mathrm{~mm}$, to $1 \mathrm{~m}$ ) during the summer season 1993-1994. DFB: distance from sea bottom. $\mathrm{r}=$ correlation coefficient. a) Traps located at $1,0.5$ and $0.25 \mathrm{~m}$ from the bottom. b)Traps located at $0.1 \mathrm{~m}$ and $5 \mathrm{~mm}$ from sea bottom. Note that the $\mathrm{x}$-axes have different scales. in the water column (up to $3.4 \mu \mathrm{g} \mathrm{l}^{-1}$, Fig. 4-c) and $\%$ POM (Fig. 4-d). For selected dates (indicated with an arrow in Fig. 3-a), the profile of the fluxes involving the five depths where traps were deployed is shown (Fig. 3-b). It could be seen that the most variable and different traps were those almost buried in the sediment. There, particle sedimentation rates were always the highest, the \% POM remaining lower than in the upper traps. The regression between TPM and $\%$ POM (Fig. 5-a and b) was always negative and variables significantly correlated $(\mathrm{p}<0.05)$ for the traps from all the depths. However, in the traps with their openings placed at the water-sediment interface, the slope as well as the \%POM were about half the values found in the other traps (Fig. 5-b).

\section{5 season}

(traps located at $5 \mathrm{~m}$ depth)

The highest particle sedimentation rate measured during 1995 was found in the traps deployed on November 24 (Fig. 6-a), with a flux $>10 \mathrm{~g} \mathrm{~m}^{-2} \mathrm{~d}^{-1}$. The same date total pigment (chlorophyll-a + phaeopigments) fluxes measured in the traps (Fig. 6a) were around $1.2 \mathrm{~g} \mathrm{~m}^{-2} \mathrm{~d}^{-1}$. This value is similar to that found on November 27, although in this case TPM was much lower. The highest organic fraction was found on November 7 (close to 80\%). The microscopical examination of the samples showed abundant cylindrical faecal pellets, probably from krill. In general, trap content was highly related to water column processes (Fig. 6-b). At the beginning 
of the study, low TPM concentrations characterised both the water column and the trap contents. On November 24 and December 1 a somewhat lower density stratification of the water column favoured particle sedimentation into the traps. Similar TPM concentrations in the water column at the end of November and on December 3 and 5 did not appear in the traps probably due to a stronger density stratification in the upper water column (at $3.5 \mathrm{~m}$ ), above the traps' location. This could have led to particle advection outside the cove. Maximum chlorophyll-a fluxes corresponded to the highest surface water column concentrations measured (Fig. 6-a and 6-b). The ratio chlorophyll-a:phaeopigments, however, was higher in the water column than in the sediment traps (not shown).

Particle analysis showed that the proportion of the particles $<2 \mu \mathrm{m}$ was smaller in the traps than in the water column (Fig. 7-a), in opposition to the distribution of particles in the 2-5 $\mu \mathrm{m}$ (not shown) and the 5-10 $\mu \mathrm{m}$ ranges (Fig. 7-b). This trend was evident during days when stratification in the water column was more conspicuous. However, no such trend was observed contrasting the traps and water column particle content during December 1 and 2 (Fig. 7-a and b), in coincidence with a weaker stratification in the water column (Fig. 6-b). Particles larger than $15 \mu \mathrm{m}$ (Fig. 7-c) were in lower concentration

a)
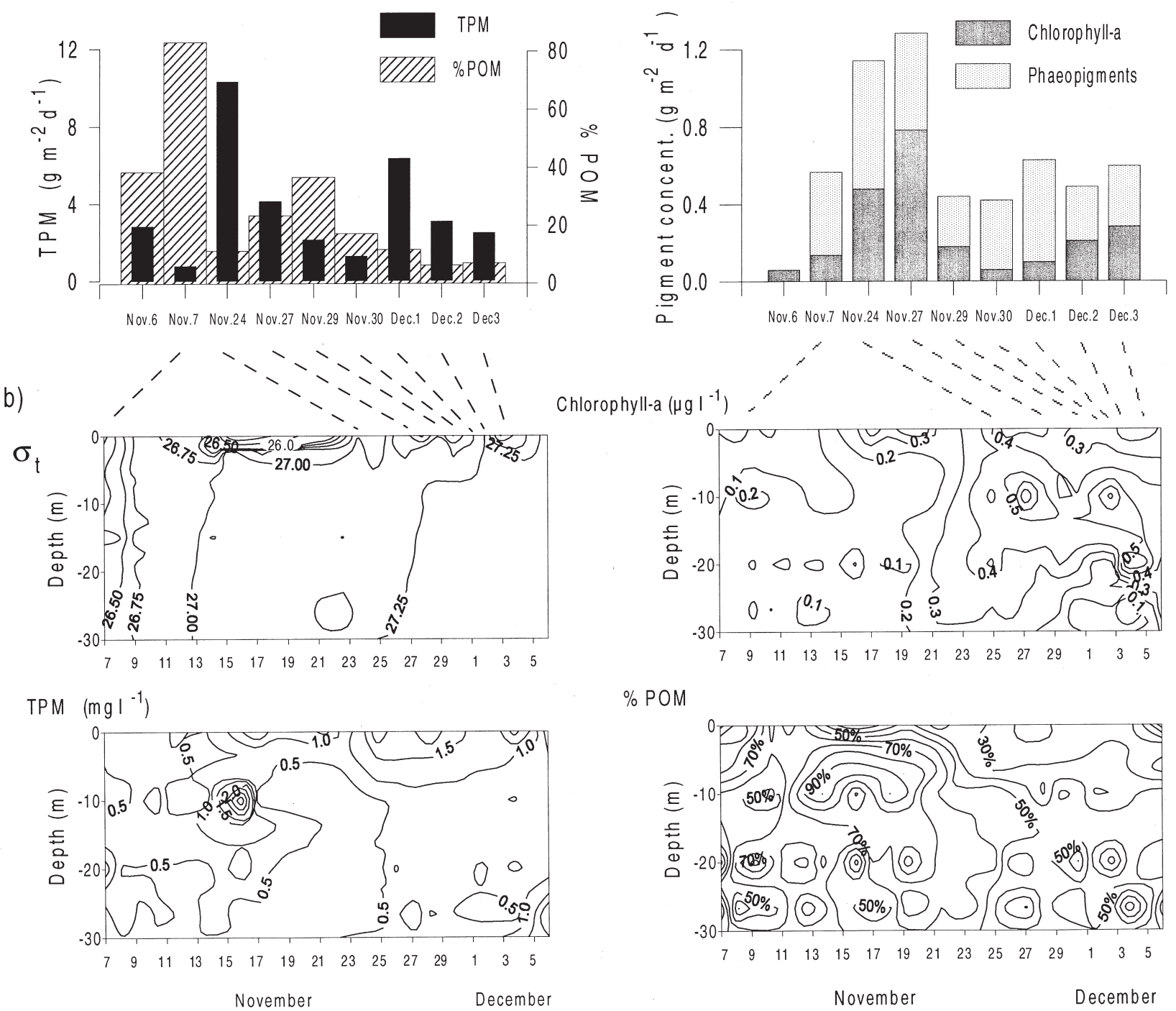

$\%$ POM

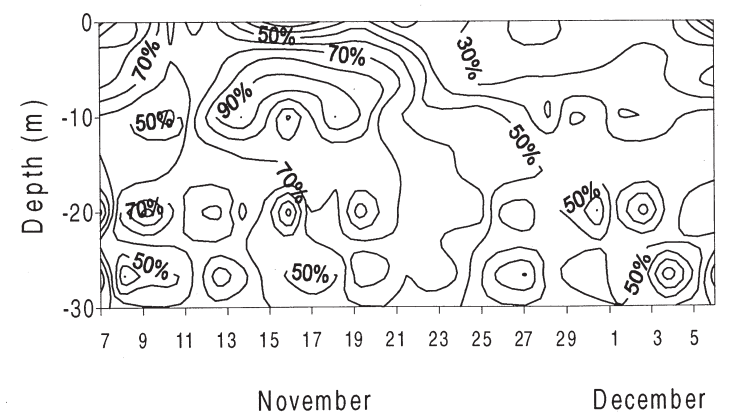

FIG. 6. - a) TPM and \%POM (left) and chlorophyll-a and phaeopigments (right) fluxes in the sediment traps deployed between November and December 1995. b) For the same period, $\sigma_{\mathrm{t}}, \mathrm{TPM}, \%$ POM and chlorophyll-a concentrations in the water column. Dates correspond to the initial deployment of the traps. 

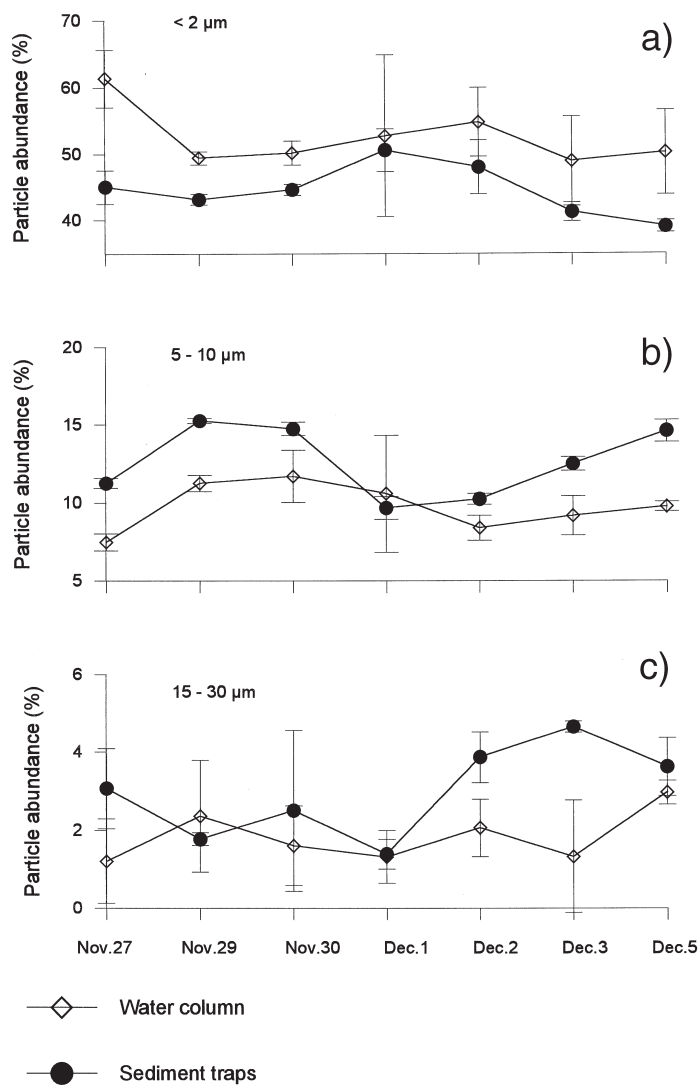

FIG. 7 - Percentual particle abundance in the sediment traps and in the water column for different particle size ranges. a) $<2 \mu \mathrm{m}$; b) 5 $10 \mu \mathrm{m}$; c) $15-30 \mu \mathrm{m}$.

than particles $<15 \mu \mathrm{m}$, and showed a higher proportion in the traps only on few occasions.

The results from the sequential trap experiment showed that the sum of the TPM collected in one day during two consecutive days -days 0 to $1(0-1)$ and 1 to 2 (1-2), resulting in the "expected" days 0 to 2 (0-2)- was about $40 \%$ (for POM: $27 \%$ ) higher than the TPM collected by the traps actually exposed during those two consecutive days (the "measured" days 0-2) (Fig. 8-a). Pigment concentration (chlorophyll-a and phaeopigments) followed a similar pattern. Considering now two consecutive samplings after 2-days exposure, and the total after 4 days vs. the expected sum, a different pattern was observed, i.e. the expected average TPM was about $17 \%$ higher than the concentrations observed in the 4-days trap (obs. 0-4) (Fig. 8a). For the pigment fluxes no evident differences were observed (Fig. 8-b). The particle size proportions expected from the sum of the single samplings did not show marked differences with the observed values either (Fig. 8-c). a)

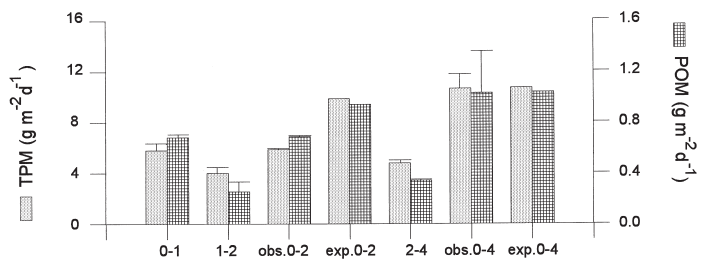

b)

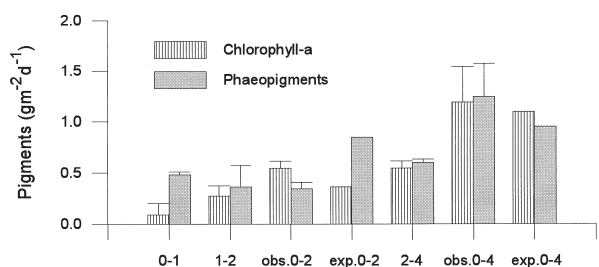

c)

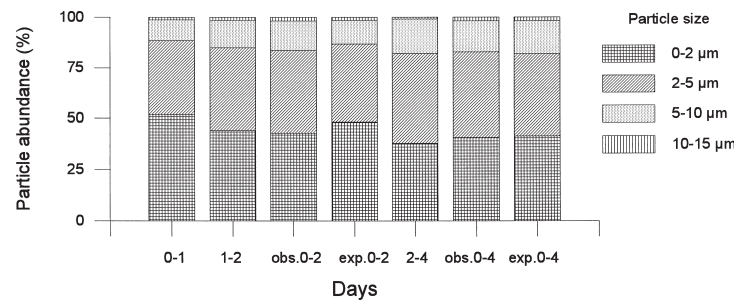

FIG. 8. - Results from the sequential trap sampling experiment: a) TPM and \%POM, b) chlorophyll-a and phaeopigments and c) percentual particle abundance for four particle size ranges. Obs. 0-2 and $0-4$ : observed fluxes or concentrations during 2 or 4 days, respectively. Exp. 0-2 and 0-4: expected fluxes or concentrations during 2 or 4 days, respectively. Vertical lines represent standard errors.

\section{DISCUSSION AND CONCLUSIONS}

Analysis of the sequential traps showed that comparing traps deployed during different intervals, the "observed" TPM amount was less that that "expected" from the sum of the TPM concentration in the traps deployed for one day. However, the difference observed was smaller after 4 days than after 2 days. This could indicate that there is a critical amount of TPM -and POM- that once accumulated inside the traps makes the decrease on a "per day" basis become less important. Although an average $17 \%$ less than the expected TPM is still elevated, it is less than the $40 \%$ observed for the sum of only two consecutive days. Additionally, no difference in pigment fluxes or particle size distribution was observed in these series. Therefore we hypothesize that although in the 5-7 days deployed traps there might have been some losses, the absolute results are still valid. Unfortunately, this experiment was done only twice, and therefore the results are not conclusive. The experiments performed were also 
related to the season and the area of study: they were done in early December, when fresh-water drainage just started. Probably under high riverine discharge these experiments might have led to different results. Therefore, we suggest that for future similar sediment trap studies in environments where the traps' recovery is not easy, a sequential sampling like the one performed in the present study should be included, in order to estimate the losses originated from a several-day sampling.

Here we present the first set of results on sediment traps in a shallow coastal Antarctic area during winter. Despite the fact that for sediment traps a short deployment time is desirable and has to be considered in future work, the \% POM inside the traps during winter was very similar to the proportion observed in the water column. Berg and Newell (1986) found for a similar environment that although in summer food quantity was higher than in other seasons, its quality (with respect to total TPM) was similar over a seasonal cycle, being even lower in summer than in autumn. In this study we found that the absolute amounts of POM in the water column were not only relatively constant but also independent of the presence of chlorophyll-a. This could lead to the conclusion that the source of POM that could be transported to the sea bottom varies seasonally: while in summer resuspension processes and some water column production could explain part of the POM observed, the winter data indicated that phytoplankton was not its primary source. The stomach contents of some benthic organisms from Potter Cove showed high POM all year round (Tatián and Sahade, 1999). This reinforces the hypothesis that other sources than water column primary production would be their main food source, as suggested by Ahn (1993) for Laternula elliptica (King and Broderip, 1831).

The differences observed in the particle fluxes toward the bottom during the various seasons studied were also related to the traps' deployment depth, which varied from some mm (traps buried in the sediments) to $25 \mathrm{~m}$ from the sea bottom. Results from the traps placed at the water-sediment interface suggest that particles trapped there may be related to local resuspension at a very small vertical scale $(\mathrm{mm})$ or to bedload transport (i.e. particles rolling on the bottom surface) which enter the traps. Current speed measurements indicate that residual and tidal current speeds are very low (in the range of 0.1 to 2.6 , and around $1 \mathrm{~cm} \mathrm{~s}^{-1}$ respectively; Roese, 1998). Such speeds could probably account only for bed-

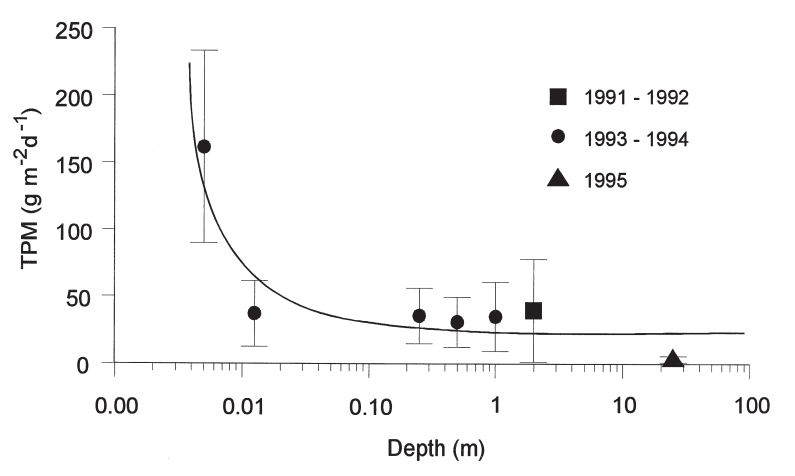

FIG. 9. - Mean values of TPM distribution as a function of the distance from the sea bottom. Data correspond to average values and standard deviations of means of all the seasons studied.

load transport of small particles. It can also be seen that the buried sediment traps contained the lowest $\%$ POM measured (Fig. 3-b), and this value is similar to the proportion that can be found in the surface sediments (Mercuri et al., 1998). This means that energy in the above mentioned vertical scale (i.e. available for buried animals) may be lower than at other distances from the bottom.

An inverse relationship between the TPM (and total POM) and the distance from the sea bottom (Fig. 9) was also observed, when combining data from all depths and all seasons studied. During spring 1993-1994 POM varied within a small scale, from the very bottom to some $10 \mathrm{~cm}$ above it. The $\%$ POM some $25-50 \mathrm{~cm}$ above the bottom was higher than that found in the buried traps. The absolute chlorophyll-a concentrations (including the phaeopigments) were higher in the buried traps than in the rest. It is noticeable that although weather conditions in the Potter Cove area were usually bad, when conditions got better, some water column production occurred (Schloss, 1997). The produced biomass could reach the sea bottom (Figs. 3-a and 4). The Potter Cove system clearly differs from other coastal zones, where phytoplankton is the main POM source, and therefore the time of the spring bloom is considered to be the most important for the nutrition of the benthic filter feeders (Navarro and Thompson, 1995). Here, like in other coastal areas where wind speed is an important forcing factor which brings bottom material into resuspension (Soniat et al., 1984; Ahn, 1997), the POM observed in the traps during most of the season was probably originated from resuspended benthic material due to strong north-westerly winds (Schloss et al., 1997). In environments where high terrestrial inputs and resuspension processes take place POM was usually 
no more than $15 \%$, with a high proportion of it being refractory for filter feeders (Soniat et al., 1984). Potter Cove particularly receives a large amount of terrigenous particles during the spring and summer months which lead to threefold increases in particle concentrations at $30 \mathrm{~m}$ depth in November and December (Kowalke, unpublished data).

The measured $<2$ and $>2 \mu \mathrm{m}$ particles are in the size range of the clay and silt fraction, respectively. Both fractions may also be constituted by organic particles, including bacteria (especially within the $<2 \mu \mathrm{m}$ size fraction). In this sense, it has been reported that organic matter is more correlated with the clay fraction than with larger particles (Mayer $e t$ al., 1985). However, we cannot differentiate these components with the methodology used in the present work. Moreover, our results show that during periods of stratification of the water column a high proportion of particles in the clay size fraction were not retained in the traps, probably being advected in the surface layer. During the same periods, particles corresponding to the silt size fraction up to $10 \mu \mathrm{m}$ were relatively more important in the traps than in the water column. The proportion of particles larger than $15 \mu \mathrm{m}$, which were in low concentration, did not differ between the trap content and the water column. On the other hand, during periods of low water column stratification, proportions of the different size fractions in the traps and in the water column were similar. These results suggest that the vertical transport of particles in surface waters can be markedly influenced by water column structure and dynamics. A variable proportion of particles within the clay size range seems to be transported horizontally due to its slow settling velocity $\left(<0.3 \mathrm{~m} \mathrm{~d}^{-1}\right.$, King, 1975) and is lost from Potter Cove. Larger particles in the silt size range sediment faster than the smaller ones (1.2 - $75.2 \mathrm{~m} \mathrm{~d}^{-1}$, King, 1975), remaining at the site in a higher proportion. This may have significant consequences for filter feeders living on the bottom (i.e., in other latitudes the clam Mytilus edulis Linné, 1758 cannot filter particles < 2 $\mu \mathrm{m}$, Vahl, 1972). Our results suggest that animals preferring particles larger than $2 \mu \mathrm{m}$ would be favoured in the process of getting their food.

\section{Particles and the benthic filter feeders}

The bottom of the inner Potter Cove is dominated by solitary ascidians, the clam Laternula elliptica and, to a much lesser extent, sponges (Sahade et al., 1998). The present results suggest that benthic organisms, including their planktotrophic stages, may have different food sources at different times of the year. Water column production and sedimentation, resuspension processes and the meltwater runoff have different effects on the availability of food for benthic organisms. In some bivalve species physiology is influenced by summer food supply, which induces growth (Thompson and Nichols, 1988) or sexual maturation (Barber and Blake, 1981). Their feeding during winter must be relocated towards dissolved organic matter (Shilling and Bosch, 1994) or bacteria (Rivkin et al., 1986).

Below $20 \mathrm{~m}$, ascidians are the dominant benthic taxon, followed in abundance by some sponge species (Sahade et al., 1998). The average height of the most important species (Molgula pedunculata Herdman, 1881) is about $25 \mathrm{~cm}$, which is close to the depth where the ratio POM/TPM is highest (Fig. 3 ). Therefore it appears that the best-positioned organisms seem to be those with their particle intake systems placed some $25-50 \mathrm{~cm}$ from the bottom (like sponges or ascidians). This means that they could probably get an important amount of POM with a smaller filtering effort than animals that have to filter huge amounts of inorganic particles before getting the same quantity of it (Pertusi, 1996). Previous information suggests that the resuspended or sinking POM is lighter than the inorganic fraction, thus sedimenting slower (Fabiano et al., 1997) and remaining available for these organisms to feed on. Lighter and smaller particles produced some meters above in the water column could, however, get lost by advection, as could be seen from the smaller proportion of these particles in the traps in contrast to their water column concentration (Fig. 8).

The relationship between organic and inorganic particles influences the feeding success of suspension feeding animals. The ascidian dominated community contrasts with others from coastal shallow environments like McMurdo Sound, where sponges dominate at the same depth (Dayton et al., 1974; Battershill, 1989). The structuring forces of inorganic particle loads, which are negligible in McMurdo Sound (Dayton and Oliver, 1977; Barry, 1988) can mainly explain this difference. Bivalves are able to close the inhalant opening (Moore, 1977) and to produce pseudofaeces (Ahn, 1993) which are expelled directly from the animal without passing the gut and consequently avoiding energy losses from processing useless items. Some mussels are able to actively select organic matter, ingesting material in excess of its proportion in the TPM 
(Soniat et al., 1984). Therefore, \% POM would not strictly be a measure of available food. These animals can benefit from silt concentration. In fact, in experiments with mussels maximum growth rates were obtained only when $5 \mathrm{mg} \mathrm{l}^{-1}$ silt was added to pure algal suspensions (Kiørboe et al., 1981). In Potter Cove silt concentrations may reach much higher values in the water-sediment interface (Mercuri et al., 1998). Clay and sand, which are present in the sediments as well (Mercuri et al., 1998), may also have a different effect on bivalve feeding; this will be tested in future studies. Ascidians as well can close the inhalant siphon (Hoyle, 1952) and contract rhythmically from time to time (squirting) to get rid of huge particle concentrations inside the mantle cave which threaten to block the filtering apparatus. Sponges, in contrast, are not able to sort particles or to close the filtering system. In consequence an ostia blockage takes place regularly during heavy sedimentation periods (Reiswig, 1971), which can lead to undernourishment or finally to suffocation of the whole animal. The dominant sponge in the area, Mycale acerata Kirkpatrick, 1907 copes with this situation by secretion of a cleaning mucus and thus dominates the sponge community in Potter Cove (Kowalke unpublished data). The amount of inorganic particles exerts a strong influence on the structure of the suspension feeding community of Potter Cove. Animals like ascidians and L. elliptica due to their capabilities in managing their suspension uptake, dominate over animals unable to regulate their nutritional needs. In the past the dilution of organic material by PIM has been considered negative for suspension feeders (Widdows et al., 1979). Oysters and other bivalves, however, can preferentially ingest organic particles and reject inorganic as pseudofaeces (Berg and Newell, 1986). Biodeposition of suspension feeding animals has been reported to contribute a major nutritional part of detritus feeding animals (Oviatt and Nixon 1975; Doering and Oviatt, 1986; Kautsky and Evans 1987; Ahn, 1993). Faecal pellets observed in some of the traps also represent a valuable food item (Handa et al., 1992). However, despite the particle uptake regulation of ascidians and L. elliptica, faecal pellets produced still exhibit an inorganic content of up to $70 \%$ (Kowalke unpublished data). This means that a vast quantity of useless particles are still processed in these animals, and consequently the nutritional value of biodeposits for coprophagic animals such as the bivalve Yoldia eightsii Couthouy in Jay, 1839 or polychaetes - which dominate the benthic assem- blages in other coastal areas (Fabiano et al., 1997) is reduced. This could contribute to explain the low densities of these animals at Potter Cove and, on the other hand, the community composition observed there.

\section{ACKNOWLEDGEMENTS}

We would like to thank Heinz Klöser for sharing part of the hydrographic data with us, and to Katrin Iken, Boris Ledesma and the divers of the Prefectura Naval Argentina for their help in the field.

\section{REFERENCES}

Ahn, I.Y. - 1993. Enhanced particle flux through the biodeposition by the Antarctic suspension-feeding bivalve in Marian Cove, King George Island. J. Exp. Mar. Biol. Ecol., 171: 75-90.

Ahn, I.Y. - 1997. Feeding ecology of the Antarctic lamellibranch Laternula elliptica (Laternulidae) in Marian Cove and vicinity, King George Island, during one austral summer. In: B. Battaglia, J. Valencia and D.W.H. Walton (eds.): Antarctic Communities: Species, Structure and Survival, pp. 142-151. Cambridge University Press, Cambridge.

Albertelli, G., R. Cattaneo-Vietti and M. Chiantore. - 1996. The influence of the organic matter flux on an Adamussium colbec$k i$ bed at Terra Nova Bay (Ross Sea, Antarctica) In: G. Albertelli, A. De Maio and M. Piccazzo (eds): Atti dell'1 $1^{\circ}$ Congresso dell'Associazione Italiana di Oceanologia e Limnologia (Sorrento, 26-28 Ottobre 1994), pp. 299-310. A.I.O.L. Genova.

Baines, S.B. and M.L. Pace. - 1994. Relationships between suspended particulate matter and sinking flux along a trophic gradient and implications for the fate of planktonic primary production. Can. J. Fish. Aquat. Sci., 51: 25-36.

Barber, B.J. and N.J. Blake. - 1981. Energy storage and utilization in relation to gametogenesis in Argopecten irradians concentricus (Say). J. Exp. Mar. Biol. Ecol., 52: 121-134.

Barnes, D.K.A. and A. Clarke. - 1995. Seasonality of feeding activity in Antarctic suspension feeders. Polar Biol., 15: 335-340.

Barry, J.P. - 1988. Hydrographic patterns in McMurdo Sound, Antarctica, and their relationship to local benthic communities. Polar Biol., 8: 377-391.

Battershill, C.N. - 1989. Distribution and abundance of benthic marine species at Cape Armitage, Ross Island, Antarctica - initial results. New Zealand Antarct. Rec., 9(2): 35-52.

Berg, J.A. and R.I.E. Newell - 1986. Temporal and spatial variations in the composition of seston available to the suspension feeder Crassostrea virginica. Estuar. Coast. Shelf Sci., 23: 387401 .

Berkman, P.A., D.S. Marks and G.P. Shreve. - 1986. Winter sediment resuspension in McMurdo Sound, Antarctica, and its ecological implications. Polar Biol., 6: 1-3.

Bloesch, J. and N.M. Burns. - 1980. A critical review of sediment trap technique. Schweiz. Z. Hydrol., 42: 15-55.

Bodungen, B. von, V. Smetacek, M.M. Tilzer and B. Zeitzschel. 1986. Primary production and sedimentation during spring in the Antarctic Peninsula region. Deep-Sea Res., 33(2): 177-194.

Brandini, F.P. and J. Rebello. - 1994. Wind field effect on hydrography and chlorophyll dynamics in the coastal pelagial of Admiralty Bay, King George Island, Antarctica. Antarct. Sci., 6(4): 433-442.

Cattaneo-Vietti, R., M. Chiantore and G. Albertelli. - 1997. The population structure and ecology of the Antarctic scallop Adamussium colbecki (Smith, 1902) at Terra Nova Bay (Ross Sea, Antarctica). Sci. Mar., 61 (Suppl. 2): 15-24.

Clarke, A. and R.J.G. Leakey. - 1996. The seasonal cycle of phytoplankton, macronutrients and the microbial community in a nearshore Antarctic marine ecosystem. Limnol. Oceanogr., 
41(6): 1281-1294.

Dayton, P.K. and J.S. Oliver. - 1977. Antarctic soft-bottom benthos in oligotrophic and eutrophic environments. Science, 197: 5558.

Dayton, P.K., G.A. Robilliard, R.T. Paine and L.B. Dayton - 1974 Biological accommodation in the benthic community at McMurdo Sound, Antarctica. Ecol. Monogr., 44: 105-128.

Doering, P.H. and C.A. Oviatt. - 1986. Application of filtration rate models to field populations of bivalves: an assessment using experimental mesocosms. Mar. Ecol. Prog. Ser., 31: 265-275.

Fabiano, M., M. Chiantore, P. Povero, R. Cattaneo-Vietti, A Pusceddu, C. Misic and G. Albertelli. - 1997. Short-term variations in particulate matter flux in Terra Nova Bay, Ross Sea. Antarct. Sci., 9 (2): 143-149.

Fofonoff, N.P. and R.C. Millard, Jr. - 1983. Algorithms for computation of fundamental properties of seawater. UNESCO Techn. Pap. Mar. Sci., 44: 1-53.

Handa, N., T. Nakatsuka, M. Fukuchi, H. Hattori and T. Hoshiai. 1992. Vertical fluxes and ecological significance of organic material during the phytoplankton bloom during austral summer in Breid Bay, Antarctica. Mar. Biol., 112: 469-478.

Hapter, R., B. Wozniak and K. Dobrowolski. - 1983. Primary production in Ezcurra Inlet during the Antarctic summer of 1977/78. Oceanologia, 15: 175-184.

Hoyle, G. - 1952. Spontaneous squirting of an ascidian, Phallusia mamillata (Cuvier). J. Mar. Biol. Ass. U.K., 31 (3): 541-562.

Kautsky, N. and S. Evans. - 1987. Role of biodeposition by Mytilus edulis in the circulation of matter and nutrients in a Baltic coastal ecosystem. Mar. Ecol. Prog. Ser., 38: 201-212.

Klöser H., G.A. Ferreyra, I.R. Schloss, G. Mercuri, F. Laturnus and A. Curtosi. - 1994a. Hydrography of Potter Cove, a small fjordlike inlet on King George Island (South Shetlands). Est. Coast Shelf Sci., 38: 523-537.

Klöser, H., G.A. Ferreyra, I.R. Schloss, G. Mercuri, F. Laturnus and A. Curtosi. -1994 b. Seasonal variations of algal growth conditions in sheltered Antarctic bays: the example of Potter Cove (King George Island, South Shetlands). J. Mar. Syst., 4: 289-301.

King, C.M. - 1975. Introduction to Marine Geology and Geomorphology. Arnold, London.

Kiørboe, T., F. Møhlenberg and O. Nøhr. - 1981. Effect of suspended bottom material on growth and energetics of Mytilus edulis. Mar. Biol., 61: 283-288.

Lange, C. and D. Boltovskoy. - 1995. Trampas de sedimento. In: K. Alveal, M.E. Ferrario, E.C. Oliveira and E. Sar (eds.): Manual de Métodos Ficológicos. pp. 93-108. Univ. Concepción, Editora Anibal Pinto S.A., Concepción,

Mayer, L.M., P.T. Rahaim, W. Guerin, S.A. Macko, L. Watling and F. E. Anderson. - 1985. Biological and granulometric controls on sedimentary organic matter of an intertidal mudflat. Est. Coast. Shelf Sci., 20: 491-503.

Mercuri, G., K. Iken, B. Ledesma and R.F. Dubois. - 1998. On the distribution patterns and density of the Antarctic infaunal bivalve Laternula elliptica in Potter Cove, King George Island, Antarctica. In: C. Wiencke, G.A. Ferreyra, W. Arntz and C. Rinaldi (eds.), The Potter Cove Coastal Ecosystem. Ber. Polarforsch.,

Moore, P.G. - 1977. Inorganic particulate suspensions in the sea and their effects on marine animals. Oceanogr. Mar. Biol. Ann. Rev., 15: 225-363.

Navarro, J.M. and R.J. Thompson. - 1995. Seasonal fluctuations in size spectra, biochemical composition and nutritive value of the seston available to a suspension feeding bivalve in a subarctic environment. Mar. Ecol. Prog. Ser., 125: 95-106.

Oviatt, C.A and S.W. Nixon - 1975. Sediment resuspension and deposition in Narragansett Bay. Estuar. Coast. Mar. Sci., 3: 201-217.

Pertusi, L.A. - 1996. Variations des caractéristiques de l'eau du front de maré. MSc Thesis, Univ. du Québec a Rimouski.

Reichardt, W. and G. Dieckmann. - 1985. Kinetics and trophic role of bacterial degradation of macro-algae in Antarctic coastal waters. In: W.R Siegfried, P.R Condy and R.M. Laws (eds.): Antarctic Nutrient Cycles and Food Webs, pp.115-122. Springer Verlag, Berlin.

Reiswig, H.M. - 1971. Particle feeding in natural populations of three marine demosponges. Biol. Bull., 141: 568-591.

Rivkin, R.B., I. Bosch, J.S. Pearse and E.J. Lessard. - 1986 Bacterivory: A novel feeding mode for asteroid larvae. Science, 233: 1311-1314.

Roese, M.C. - 1998. Aspectos de la circulación en Caleta Potter, Islas Shetland del Sur, Antártida. Trabajo de Seminario. Inst. Tecnol. Buenos Aires, Oceanografía.

Sahade, R., M. Tatián, J. Kowalke, S. Kuehne and G. Esnal. - 1998. Benthic faunal associations on soft bottom at Potter Cove, King George Island, Antarctica. Polar Biol., 19: 85-91.

SCAR - 1994. Coastal and Shelf Ecology of the Antarctic Sea-Ice Zone (CS-EASIZ). SCAR Bull., 10: 1-20.

Schloss, I.R., G.A. Ferreyra, A. Curtosi, H. Klöser, G. Mercuri and E. Pinola. - 1997. Factors governing phytoplankton and particulate matter variation in Potter Cove, King George Island (Antarctica). In: B. Battaglia, J. Valencia and D. W. H. Walton (eds.): Antarctic Communities: Species, Structure and Survival, pp: 135-141. Cambridge University Press, Cambridge.

Schloss, I.R. - 1997. Escalas temporo-espaciales de variabilidad del fitoplancton costero antártico. PhD Thesis, Univ. Buenos Aires.

Shilling, F.M. and I. Bosch. - 1994. Pre-feeding embryos of Antarctic and temperate echinoderms use dissolved organic material for growth and metabolic needs. Mar. Ecol. Prog. Ser., 109: 173-181.

Soniat, T.M., S.M. Ray and L.M. Jeffrey. - 1984. Components of the seston and possible available food for oysters in Galveston Bay, Texas. Contrib. Mar. Sci., 27: 127-141

Strickland, J.D.H. and D.R. Parsons. - 1972. A practical handbook of seawater analysis. J. Fish. Res. Bd. Can. Bull., 167: 1-310.

Tatián, M. and R. Sahade. - 1999. Niveles de materia orgánica en los contenidos estomacales de ascidias (Tunicata, Ascidiacea) de la Isla 25 de Mayo, Antartida. In: C.A. Rinaldi (ed.), IV Jornadas sobre Investigaciones Antárticas. Tomo I: Comunicaciones: 81.

Thompson, J.K. and F.H. Nichols. - 1988. Food availability controls seasonal cycle of growth in Macoma balthica (L.) in San Francisco Bay, California. J. Exp. Mar. Biol. Ecol., 116: 43-61.

Urban, H.-J. and G. Mercuri. - 1998. On the population dynamics of the bivalve Laternula elliptica from Potter Cove (King George Island, Antarctic Peninsula): Influence of water currents explaining the occurrence of two subpopulations. Antarct. Sci., 10 (2): 153-160.

Vahl, O. - 1972. Efficiency of particle retention in Mytilus edulis. Ophelia, 10: 17-25

Wassman, P. - 1991. Dynamics of primary production and sedimentation in shallow fjords and polls of western Norway. Oceanogr. Mar. Biol. Annu. Rev., 29: 87-154.

Widdows, J., P. Fieth and C.M. Worral. - 1979. Relationships between seston, available food and feeding activity in the common mussel Mytilus edulis. Mar. Biol., 50: 95-207. 